\title{
University of Cambridge, Cavendish Laboratory （ケンブリッジ大学キャベンディッシュ研究所）
}

\section{1.はじめに}

2005 年の 9 月より 2 年間，イギリスのケンブリッジ大 学物理学部に在籍し, 研究活動に従事するという好機を頂 いた.ここでは, 現地での研究活動に加え, ケンブリッジ の風土やそこでの生活など振り返って紹介したい.

\section{2 ．ケンブリッジの風土と歴史}

イギリスの東部，ロンドンのキングスクロス駅から電車 で 1 時間足らずのところにケンブリッジは位置する. 人口 10 万余りのこの街は, 自転車があれば街中を隈なく探索 できる小さな街. 世界的に有名な大学町であることは言う までもないが，特筆すべき点は大学の存在感の大きさであ る. 街の中心部の大部分を大学関連の建物が占めるため, 街の中に大学があるというよりも, 街そのものが大学とい う印象を受ける。 また, 街の随所に広大な緑が広がってお り, 季節の移ろいに合わせて種々の野鳥や小動物を眼にし ては，自然の豊かさを実感した。

イギリスは歴史・伝統を尊重する国. イギリスで生活し ていれば，随所で昔話に遭遇する．パントと呼ばれる手漕 ぎの船で町を流れるケム川を行くと, ガイドの学生さんが 雑多な昔話を披露してくれた. 少なくとも875 年にはケム 川の辺にケンブリッジという名の町はあったそうだ。その ケム川にかかる橋が街の由来とされている $(\mathrm{Cam}-$ Bridge). その町に大学が設立されたのは 13 世紀の初めで ある.イギリスで最も古いオックスフォード大学から一派 が移り住み, 大学の原形が出来上がったそうだ1).ケンブ リッジ及びオックスフォード大学を語る上では,「カレッ ジ」という特殊な大学のシステムについて言及すべきであ ろう。これら 2 大学は我々に馴染みの深い「学部」という 組織に加えて，「カレッジ」という独立した組織を別に有 している.「学部」とは学生が専門科目の受講及び研究を 行う場である.それに対して,「カレッジ」とは学生が専 門科目以外の科目を受講する場であり, 尚且つ, 大学寮の ように共に生活をし, 課外活動を行う場である. 通常の「学 部」を縦の組織として捉えるならば,「カレッジ」は横の 組織として捉えることができよう. 何故ならばカレッジは

\footnotetext{
* Hirota, Yoshihito

三井化学(株) 開発センター 複合技術開発部

袖ヶ浦市長浦 580-32（テ 299-0265）

2008.2.8 受理
}

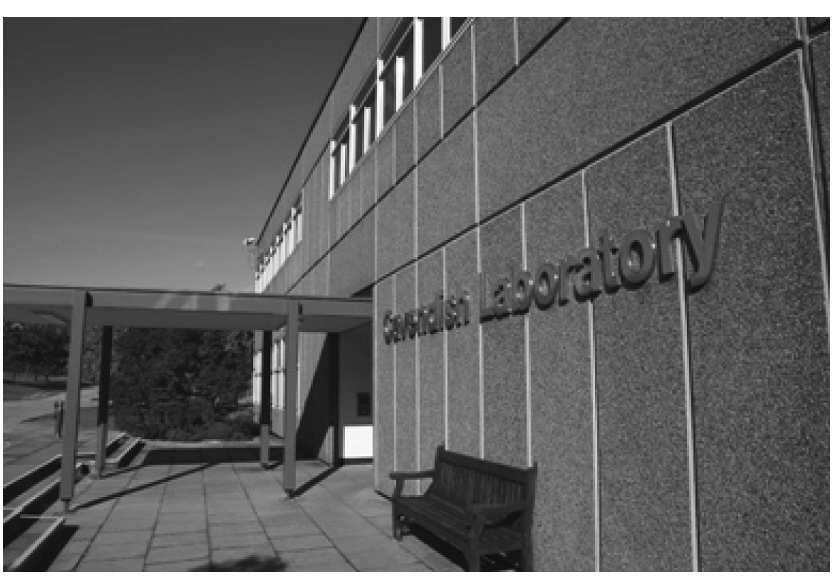

図 1 キャベンディッシュ研究所の正面玄関

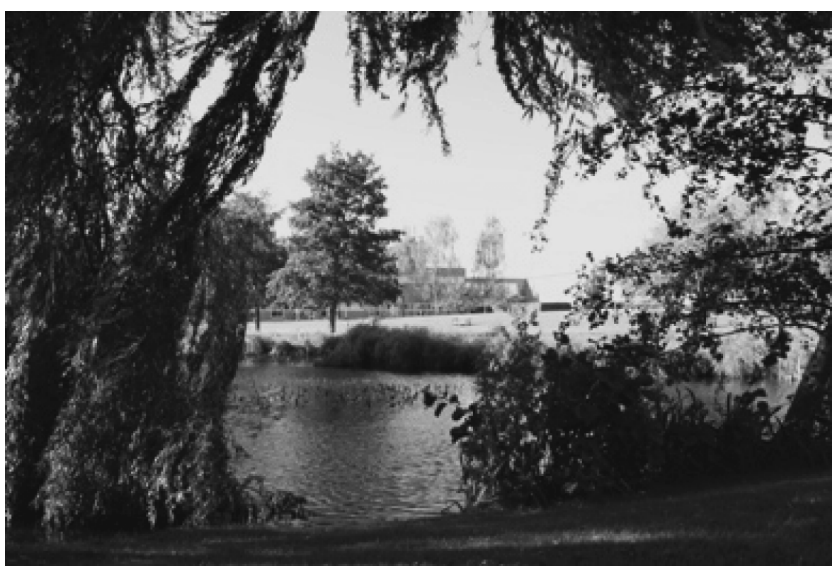

図 2 中庭から眺めたキャベンディッシュ研究所

種々の学問を専攻とする学生が集い語らうことのできる場 であるためである. 興味深いのはカレッジによって学生数 や資金，図書室などの設備面が同じではないこと．裕福な カレッジもあれば,そうでないカレッジもある.ケンブリッ ジには 31 のカレッジがあり，4大カレッジとして数え上 げられているのはトリニティー, セントジョーンズ，キン グス，そしてクイーンズカレッジである.

幸運にも2006 年の 10 月より M.Phil. (Master of Philosophy；日本の修士号に近い）の学生としてクイーンズ カレッジに所属することができた。私が思うにカレッジの 醍醐味とは伝統的で格式高い社交の場に参加できることで はなかろうか. 各カレッジでは定期的に晚餐会が催され， 


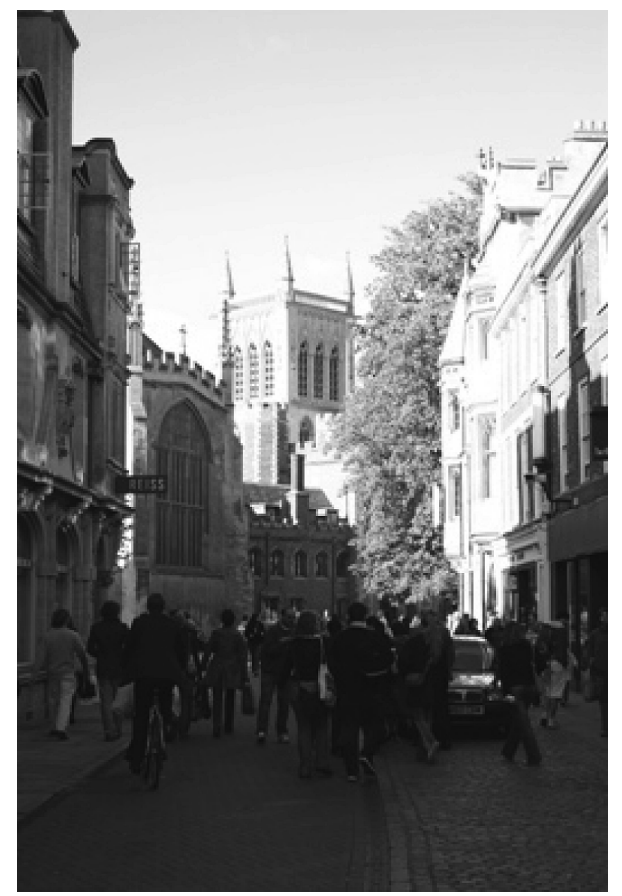

図 3 街の様子 正面に見えるのはセントジョーンズカ レッジ. その左隣がトリニティーカレッジ.

クイーンズカレッジの場合には 15 世紀に建てられた建造 物が今でもその会場に使用されている(図 5). 晚餐会で は 3〜 5品のコース料理が振舞われ，一般的なイギリス料 理の前評判とは裏腹に味は非常に良かった. 特に印象深 かったのは国際色豊かな参加者とそんな彼らのマナー及び 社交性の高さである. 参加者の大半は 20 代前半と思われ るが，このような環境で育つことで彼らの教養や社交性は 培われるのであろう. 非常に贅沢な場であると感じた。

\section{3 . Biological and Soft Systems group}

さて, 筆者は物理学部の Biological and Soft Systems （BSS）という研究グループに 2 年間在籍していた. 物理 学部（キャベンデイッシュ研究所）は市街地から自転車で 10 分程度のところに位置する西ケンブリッジと呼ばれる 地域にある.現在の研究所は 2 代目で, 1970 年代の初めに 市街地から今の場所に引っ越してきた2). 同じ敷地内に 3 代目のキャベンディッシュ研究所が今まさに建設中である.

研究所を訪れた際, 是非一度足を運んで頂きたいのが建 物の一角にある小さな博物館である。この研究所で上げら れた数々の輝かしい業績が簡単な説明と共に展示されてお り, 科学史に残る偉業の片鱗を垣間見ることができる. 中 には Maxwell や J.J.Thomson が使用した実験装置も展示 されている.

BSS グループの研究内容は高分子物理学から生物物理 学まで多岐に渡る. 理論物理学のみではなく, 実験物理学 を同程度以上に重んじているという印象を受けた，BSS グループには 3 名の教授 (Athene Donald, Ullrich Steiner, Eugene Terentjev) と 1 名の名誉教授 (Sir Sam Edwards) が扔られる. Edward 先生はまだまだ精力的に活躍されて おり, 先生の授業を 2 度ほど拝聴する機会を頂けた. 昨今 は粉流体の研究をされている. 教授陣の他には約 20 名の

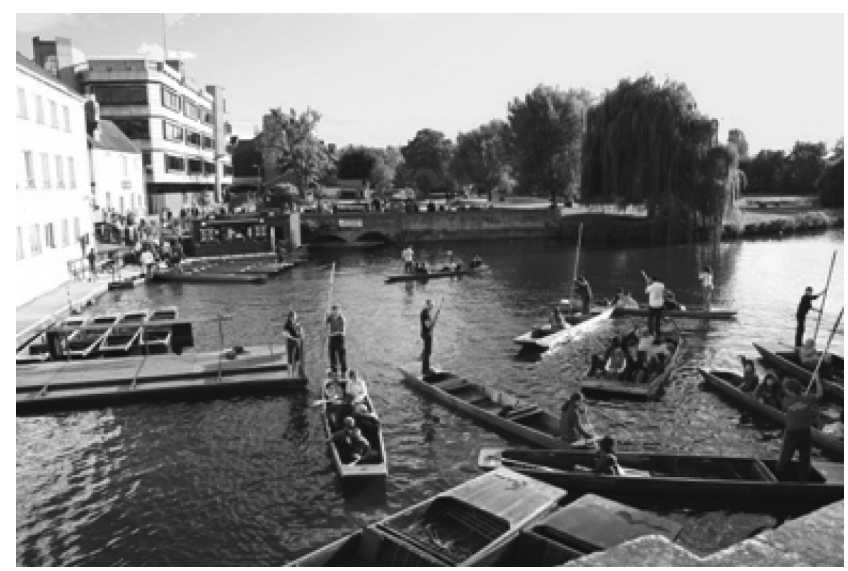

図 4 ケム川の風景 長い棒を川底に突き刺してパントと 呼ばれる船を操縦する. 川に落ちる人もしばしば.

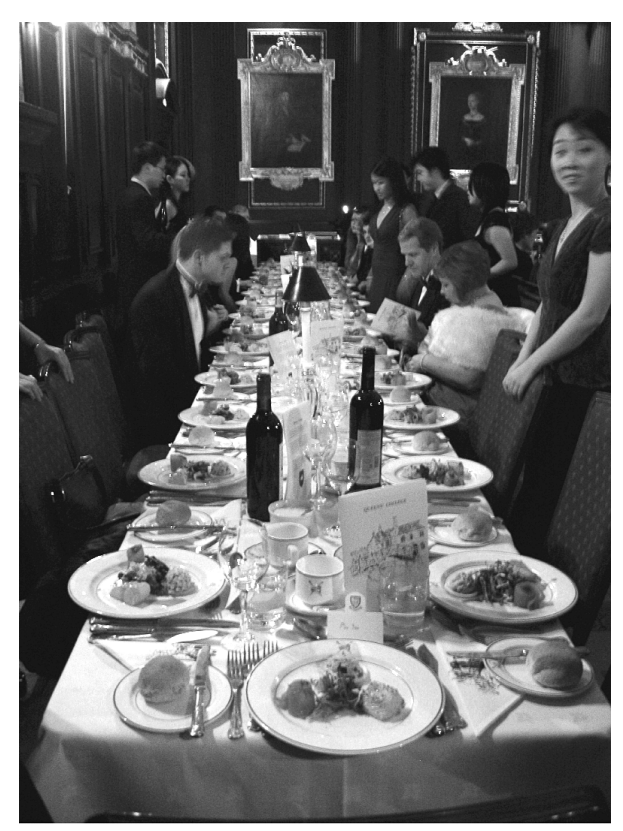

図 5 クイーンズカレッジで行われた晚餐会の様子

スタッフが㧍り，学生とビジターを合わせると総計 80 名 近くの大所带となる.

グループ全体の研究内容をキーワードとしてリストアッ プすると ${ }^{3)}$,

・ソフトマター物性（液晶, ポリマー, 生体材料を中心に 理論, シミュレーション,招よび実験的手法による研究)

・タンパク質の折りたたみと折りたたみ異常

・表面・界面での流体挙動

·医学画像

・生体システムのモデル化

・自己会合抒よび凝集の制御

非常に広範な研究領域を有する BSS グループであるが, その基盤をなしているのは高分子物理学と言っても過言で はなからう. 高分子物理学者から見て生体高分子はどのよ うに魅力的なのか? Athene Donald 日く, 液晶や高分子 の分野で発展されてきたりフトマター物理学は, タンパク 質や核酸, 糖類などの生体高分子の生体内での挙動に関し て，普遍的な真理を見つけ出すことに大きく貢献できるで 
あろうとその可能性に期待が达められている4)。例えば, 折りたたみ異常を起こしたタンパク質はアミロイド原繊維 と呼ばれる瀻維状の会合体を形成することが知られている。 このようなタンパク質の纎維化はアルッハイマー病や BSE (牛海綿状脳症) の上うな病気の発生と密接な関係が あるとされている。このような現象はタンパク質の種類に よらず観察されており，その普遍性が考えられる。また， 合成高分子における球晶のような高次の会合体を形成する ことも知られている.

筆者は Terentjev 教授のもと, コレステリック液晶エ ラストマーの研究を行った.この材料は液晶相の 1 つであ るコレステリック相（液晶性分子が一軸配向した平面が, その配向軸を連続的に回転させながら積み重なった様相） を有しながら，エラストマーとしての弾性を有している. コレステリック相はその周期構造に対応する構造色を示し, 鮮やかな呈色が観察される。コレステリック液晶エラスト マーの興味染い特性は, この周期長が引張により可逆的に 制御できる点である。すなわち，材料をコレステリックの 螺旋軸に対して垂直方向に引っ張ることで，観察される呈 色が赤から青へとブルーシフトする．また，更に興味深い ことにこの材料を引張すると, 光学活性な螺旋構造から光 学非活性な周期構造へと転移する現象が観察される 者らはこれら特性に着目して波長可変レーザーへの応用を 視野に入れた研究を行い, 応力印加によるレーザー波長の 制御を実現した。

\section{4.おわりに}

以上，ケンブリッジでの生活を振り返って報告した，研 究内容それ自体は成形加工と直接関連していないことをご 了承いただきたい。しかしながら，BSSグループの主要 な研究領域である「ソフトマター物理」は高分子から液晶, コロイド，生体材料まで広く包括するものであり，近年， その重要性から益々の注目を集めている。成形加工もまた 大いに関連する分野であると断言してよかろう。そうであ るならば，成形加工の分野で培った知見が生物物理を含む 他の学問領域でも適用され得るし，また逆に，それら他の 学問領域で発展されてきた知見を成形加工に取り入れるこ とで，斬新な材料設計が可能となるのかもしれない. ケン ブリッジのような自由かつ開放的な雲囲気のもとでは，こ れくらいの大風呂敷がちょうど良いように思われる.

\section{参 考 資 料}

1) http ://en.wikipedia.org/wiki/University_of_cambri dge

2) http://en.wikipedia.org/wiki/Cavendish_lab

3 ) http ://www.bss.phy.cam.ac.uk/

4) Donald, A. M. : J. Polym. Sci. Part B : Polymer Phys 2007, 45, 3257

5 ) Warner, M., Terentjev, E. M., Meyer, R. B. and Mao, Y. : Phys. Rev. Lett., 85, $2320(2000)$

\section{賛助会員の皆様へ \\ 「製品・技術紹介」へご投稿下さい}

「成形加工」誌には，「製品・技術紹介」のコーナーを設けています.

「製品・技術紹介」はプラスチック成形加工学会の賛助会員が自社の製品・技術を広く会員に アピールするための記事で, 詳細は以下のとおりです.

1. 賛助会員企業の開発した装置・機械・材料等，各種製品と技術を資料・図表・写真等によ り紹介するもの.

2. 賛助会員企業に属する個人（または複数名）の記名入り記事とし, 長さは刷上がり 1 頁と する（図表を含み 2300 字程度, 原稿 1 頁当たり 26 字 $\times 27$ 行 $=702$ 文字で作成）.

3 . 掲載料は無料（ただしカラー印刷の場合は実費負担）.

この「製品・技術紹介」への投稿を，是非ご検討下さい.

「製品・技術紹介」は，投稿順（抜閲後）に随時掲載しております。記事のスタイル，内容等 につきましてはすでに掲載されている幾つかの記事をご参照下さい.

「成形加工」編集委員長 大嶋正裕 